\author{
Hanna SOMMER ${ }^{1}$ \\ Grzegorz ZAKRZEWSKI ${ }^{2}$
}

\title{
ZAŁOŻENIA DLA EDUKACJI EKOLOGICZNEJ CZY BEZPIECZEŃSTWA EKOLOGICZNEGO
}

\begin{abstract}
Artykuł zawiera krótki rys historyczny nauki zwanej ekologią, przedstawia podstawowe definicje oraz uczonych, którzy wprowadzili nową terminologię do słownika ekologicznego. W dalszej części autorzy wskazują na zależności między szeroko rozumianą świadomością ekologiczną a edukacją ekologiczną. Przytoczone przez autorów informacje wskazują na rangę, jaką dla współczesnego społeczeństwa jest edukacja ekologiczna.

Edukacja ekologiczna pełni bardzo ważną rolę we współczesnym świecie, w którym obserwuje się szybkie tempo wpływania na środowisko przyrodnicze. Jest ona procesem psychologiczno-pedagogicznym, który ma wpływ na kształtowanie świadomości ekologicznej. Stanowi istotny element naszego przystosowania do środowiska, w którym funkcjonujemy. Główne jej zadania najczęściej sprowadzają się do wskazywania zagrożeń środowiska przyrodniczego, przekazywania wiedzy teoretycznej, którą należy wcielać w praktyczne działania. Celem edukacji ekologicznej powinno być kształtowanie sfery emocji, która wpłynie na zwiększenie efektywności postrzegania, myślenia i działania. Aby spełniała ona swoje zadania powinna obejmować wszystkie poziomy edukacji formalnej oraz nieformalnej. Przede wszystkim trzeba edukować młode pokolenia i w ten sposób kształtować mentalność społeczeństwa.

Troska o miejsce, w którym żyjemy, pracujemy oraz odpoczywamy powinna prowadzić do wzmożonych działań na rzecz promocji edukacji ekologicznej jednocześnie teoretyków i praktyków. Troska ta powinna wynikać z występujących zagrożeń ekologicznych i środowiskowych, które są niebezpieczne dla zdrowia oraz życia współczesnego człowieka.

Autorzy zastanawiają się, czy uprawnione staje się ewolucyjne „przejście” pojęć typowych i przypisywanych ekologii do bezpieczeństwa ekologicznego.
\end{abstract}

Słowa kluczowe: ekologia, ekologiczna: świadomość, edukacja, wyobraźnia, bezpieczeństwo ekologiczne.

\section{WPROWADZENIE}

Jednym z podstawowych warunków skutecznej realizacji polityki ekologicznej państwa jest edukacja jego społeczeństwa. Powinna być realizowana nie tylko przez zinstytucjonalizowane wprowadzanie kolejnych przedmiotów nauczania, lecz znajdować również wyraz w programie niekonwencjonalnych, a jednocześnie efektywnych działań, adresowanych do poszczególnych środowisk. Należy przy tym przyjąć, że jest to jeden z najskuteczniejszych

${ }^{1}$ Dr Hanna Sommer, Katedra Nauk Humanistycznych, Wydział Zarządzania, Politechnika Rzeszowska, Al. Powstańców Warszawy 8, 35-959 Rzeszów; e-mail: hansom@prz.edu.pl.

${ }^{2}$ Dr inż. Grzegorz Zakrzewski, Wydział Finansów i Zarządzania, Wyższa Szkoła Bankowa w Gdańsku, Al. Grunwaldzka 238, 80-266 Gdańsk; e-mail: gzakrzewski@wsb.gda.pl. 
sposobów ,inwestowania” w zmiany świadomości ekologicznej. Zmiany te powinny być traktowane, jako podstawa powodzenia i akceptacji społecznej ukierunkowanej na ekorozwój.

W krajach Europy Zachodniej proces odnowy i ochrony naturalnego środowiska człowieka na dobre rozpoczął się po dramatycznym apelu wygłoszonym do narodów świata przez sekretarza generalnego Organizacji Narodów Zjednoczonych Sithu U Thanta ${ }^{3}$ na 23 sesji ONZ 26.05.1969 r. pt. „Człowiek i jego środowisko”.

Przeobrażenia życia społeczno-gospodarczego Polski w końcówce lat 80. ubiegłego wieku, w tym przyspieszenie rozwoju gospodarczego, przyniosły nowe zagrożenia, w tym również zagrożenia ekologiczne, którym poprzedni system nie nadawał należytego znaczenia. Postępująca i nabierająca tempa integracja społeczno-ekonomiczna z rozwiniętymi gospodarczo państwami Europy Zachodniej przyczyniła się do swoistego „obudzenia się” świadomości ekologicznej Polaków.

\section{KSZTAŁTOWANIE SIE ZACHOWAŃ SPOŁECZNYCH}

We wspomnianym okresie, w różnych środowiskach polskiego społeczeństwa pojawiły się dotychczas szerokiemu kręgowi nieznane terminy: „ekologia”, „ochrona i kształtowanie naturalnego środowiska człowieka”. Pojęcia te, choć nie nowe, w przeróżny sposób definiowane zrobiły zawrotną karierę, wdzierając się do wszystkich sfer działalności człowieka - od materialnej, po kulturową i polityczną włącznie.

Zaczęły, jak grzyby po deszczu, wyrastać hasła mające charakter reklamowy i komercyjny. Dzisiaj przyzwyczailiśmy się do pojęć: „ekologiczna żywność”, „ekologiczna odzież”, ,ekologiczne planowanie rodziny” itp. I nikogo już one nie dziwią ${ }^{4}$.

Ekologia jest dziedziną wiedzy niesłychanie interdyscyplinarną (wykorzystuje pojęcia filozoficzne, osiągnięcia nauk biologiczno-chemicznych i innych, wdraża aparat matematyczny, który w sposób nieomal doskonały opisuje zjawiska złożone, jak np. taksonomiczne metody jakości wód ekosystemów. Z tego tytułu na temat ekologii wypowiadają się ludzie z różnych obszarów naukowych i pozanaukowych. Wykorzystując boom ekologiczny, wprowadzają, często zbyt pochopnie, słowo „ekologiczny” do różnych nowo tworzonych przedmiotów, zawodów, kursów itp. Stąd też wzięły się następujące ,prawdziwki” słowne: ekologiczny odkurzacz, chemia gospodarcza z elementami ekologii, ekologiczny wypoczynek, ekologiczne szkolenie itp.

Uważny czytelnik, chcący śledzić literaturę przedmiotu, może zagubić się w potoku czynności, zjawisk, przedmiotów czy też zagadnień mających przymiotnik „ekologiczny”. W konsekwencji tego zamieszania rodzi się pytanie: czy jest to moda, na którą zachorował świat w końcu XX wieku, czy raczej potrzeba chwili?. Chwili, w której trzeba bić na alarm, aby słowu „ekologia” nadać właściwe znaczenie, aby zdać sobie w końcu sprawę, że świat stanął nad przepaścią ekologiczną i wskutek każdego nierozważnego działania ludzkość poniesie nieodwracalne straty (od genetycznych, ekonomicznych, społecznych, a na kulturowych kończąc).

\footnotetext{
${ }^{3}$ Sithu U Thant (ur. 22 stycznia 1909 r., Pantanaw, Birma, zm. 25 listopada 1974 r. w Nowym Jorku) - polityk birmański, trzeci sekretarz generalny ONZ; od 30 listopada 1961 r. do 31 grudnia 1971 r. ${ }^{4}$ G. Zakrzewski, Koncepcja edukacji środowiskowej w MW RP, „Przegląd Morski” 1995/3, s. 23.
} 
Każdorazowe wprowadzenie nowych form użytkowania środowiska naturalnego narusza i zmienia pierwotny układ przyrodniczy. Stąd wniosek, że nie ma działań, które byłyby obojętne dla środowiska przyrodniczego.

Przez wiele tysięcy lat poczynania człowieka przynosiły zaledwie ograniczone, lokalne skutki w środowisku przyrodniczym. Obecna jego działalność powoduje niewspółmiernie większe zmiany, prowadzące nierzadko do wielkich, trudno odwracalnych katastrof ekologicznych. Transgraniczne zanieczyszczenia powietrza, morza czy wszechoceanu światowego wskazują, jak dalekosiężne są skutki nawet punktowych źródeł zanieczyszczenia atmosfery i hydrosfery. Okazuje się, że coraz częściej zbliżamy się lub przekraczamy bariery środowiska przyrodniczego, co z kolei grozi utratą jego zdolności do samoregulacji. Na potrzeby planistów przestrzennych sformułowane zostało pojęcie: „,krańcowe progi przyrodnicze", czyli granica wytrzymałości środowiska przyrodniczego (lub danego ekosystemu), której przekroczenie uruchamia reakcję łańcuchową prowadzącą do nieodwracalnych zniszczeń tego środowiska lub jego podstawowych elementów5.

Jerzy Kozłowski pisze o metodzie krańcowych progów przyrodniczych (kpp) - to „granica zakłóceń, poza którą dany ekosystem staje się niezdolny, aby powrócić do właściwego mu stanu i równowagi” a jej przekroczenie ,uruchamia reakcję łańcuchową prowadzącą do nieodwracalnych zniszczeń przyrodniczych całego ekosystemu, albo jego podstawowych elementów"6.

Spojrzeniu na przyrodę w praktyce wciąż towarzyszy kartezjański punkt widzenia świata, zachęcający do dokonania ,wielkiego skoku”. Jednakże nowe odkrycia i technologie nie odwracają procesu degradacji Ziemi oraz genetycznych właściwości „homo sapiens”. Problemów cywilizacji „,postindustrialnej” nie da się rozwiązać za pomocą koncepcji rewolucji przemysłowej. Aby kolejne stulecie nie było wiekiem paradoksu, trzeba dokonać przebudowy świadomości, jeżeli nie podświadomości. Nie można zapominać o zmyśle ciągłości, zmyśle związku i zmyśle kierunku.

Ktoś pisząc o rewolucji francuskiej stwierdził: „Społeczeństwo jest rzeczywiście umową wiążącą nie tylko żyjących, lecz także i zmarłych oraz tych, którzy mają się urodzić”. W tych słowach odzwierciedla się filozofia „katedr”, budowanych przez wieki nie z kamienia i szkła, lecz z mózgów i oleju w głowie. Dlatego musimy patrzeć w przyszłość i zacząć myśleć o przyszłych pokoleniach. „Współczesne społeczeństwo nie zna sąsiadów” - powiedział Disraeli ponad sto lat temu i od tego czasu nic się nie zmieniło. Samotność może stać się prawdziwą chorobą następnego stulecia, jeśli ludzie (i państwa) pozostaną egoistami, w pojedynkę walczącymi z katastrofami ekologicznymi. A przecież walka o środowisko wymaga wciąż wzmożonego wysiłku wobec konieczności tworzenia nowych i modyfikowania starych systemów informacji, planowania przestrzennego, finansów publicznych i prawa ${ }^{7}$.

Stosunek człowieka do przyrody powinien być partnerski, tzn., że człowiek musi z przyrodą współżyć, współdziałać, współpracować. Konsekwencją tego wniosku jest szacunek do przyrody, zaniechanie lub ograniczenie działań, które powodują dewastację bądź degradację przyrody. Człowiek, niszcząc przyrodę jako partnera, szkodzi sam sobie.

\footnotetext{
5 S. Borsuk (red.), Ochrona i ksztattowanie środowiska, Toruń-Bydgoszcz 1994, s. 153.

${ }^{6}$ cejsh.icm.edu.pl/cejsh/element/...PRM_2011-1-2_04_Kozlowski.pdf (dostęp: 11.10.2016 r.).

${ }^{7}$ L. Żmudziński (red.), Morskie Obszary Chronione w polskiej strefie brzegowej-zakres, forma i sposoby ochrony, Materiaty z sympozjum Centrum Biologii Morza PAN, Gdynia, 26 lutego 1998.
} 
Takie działanie jest nierozumne, niegodne ludzkości. Współczesny człowiek musi te podstawowe prawdy przyjąć i ściśle przestrzegać, jeśli chce nadal trwać i przetrwać. Niszczona i kaleczona przyroda wcześniej czy później nieodwołalnie „zemści się”, gdyż jej prawa są nieubłagane i działają z żelazną konsekwencją ${ }^{8}$.

Termin ,,ekologia” do nauk przyrodniczych wprowadzony został w 1869 r. przez niemieckiego zoologa Ernesta Haeckla jako jedna z wielu propozycji określenia wiedzy o związkach organizmów (zwierzą) z zasiedlanym przez nie środowisku oraz o wzajemnych relacjach między organizmami. W krótkim czasie termin ten znalazł się w naukowym obiegu, zyskując coraz nowe, rozszerzone znaczenia. Wyodrębnienie się ekologii, jako dyscypliny nauk biologicznych, dysponującej własną metodologią i terminologią oraz początkowy jej rozwój związany jest z postaciami dwóch badaczy: Amerykanina Frederica E. Celemensa oraz Anglika Arthrura G. Tansey’a. Ich zasługą jest wskazanie związków ekologii z innymi naukami biologicznymi ${ }^{9}$.

Punktem przełomowym w rozwoju ekologii było wprowadzenie w 1935 r. przez Tansey'a pojęcia ,ekosystemu” jako podstawowej, ekologicznej jednostki funkcjonalno-przestrzennej. Ekosystem stanowi obszar o względnie jednorodnych warunkach abiotycznych (biotop), zajęty przez odpowiadający tym warunkom zbiór gatunków powiązanych zależnościami troficznymi i paratroficznymi, przez który płynie strumień energii i materii. Za ekosystem uznać też można obszar zagospodarowany technicznie, jeżeli spełnia przytoczone wyżej warunki ${ }^{10}$. Zgodnie $\mathrm{z}$ tą definicją ekosystem tworzą dwa pozostające ze sobą w ścisłym związku komponenty ${ }^{11}$ :

- nieożywiony (biotop, zw. też siedliskiem), na który składają się gleba, woda i powietrze $\mathrm{z}$ ich właściwościami fizykochemicznymi, oraz klimat;

- ożywiony (biocenoza), złożony z kombinacji gatunków właściwych danemu biotopowi w danych warunkach geograficznych.

Procesem decydującym o funkcjonowaniu ekosystemów, a tym samym podtrzymaniu zjawiska życia na Ziemi, jest przepływ strumienia energii i materii.

Obok pojęcia ekosystemu drugim, niezmiernie istotnym dla zrozumienia procesów i zależności ekologicznych, jest pojęcie ,niszy ekologicznej”’. Wprowadzenie go do słownika ekologicznego przypisuje się Grinnelowi. Termin ten, ze względu na swoją złożoność, jest rozmaicie interpretowany przez ekologów, przy czym wydaje się, że najpełniejszą jego definicję podał Odum. Określił on niszę ekologiczną jako „miejsce lub status organizmu w obrębie danego zespołu i ekosystemu wynikające ze strukturalnych przystosowań organizmu, jego reakcji fizjologicznych oraz specyficznego behawioru (wrodzonego i/lub wyuczonego)”. Podkreśla on, że „nisza ekologiczna organizmu zależy nie tylko od tego, gdzie organizm żyje, ale również od tego, co organizm ten robi" ${ }^{12}$. Na bazie doświadczeń autekologii wyłonił się nowy kierunek zainteresowań ekologii - ekologia człowieka gdzie, obok czynników abiotycznych i biotycznych siedliska, uwzględniać zaczęto również społeczne i kulturowe uwarunkowania egzystencji populacji ludzkiej.

\footnotetext{
${ }^{8}$ St. Bieszczad, J. Sobota (red.), Zagrożenie, ochrona i ksztattowanie środowiska przyrodniczo-rolniczego, Wrocław 1993, s. 5.

9 S. Borsuk (red.), Ochrona..., s. 6.

${ }^{10}$ Ibidem, s. 9.

11 Ibidem, s. 9.

12 Ibidem, s. 10.
} 
Zdobycze ekologii w postaci zrozumienia zasad, mechanizmów i prawidłowości funkcjonowania układów przyrodniczych dały podstawę do racjonalnego gospodarowania zasobami środowiska i ich ochrony. Stały się teoretyczną wykładnią działań praktycznych w środowisku.

Pojęcia ,ochrona przyrody” i ,ochrona środowiska” oznaczają dwie sfery działalności człowieka, które chociaż silnie się zazębiają, nie są jednak tożsame ze względu na cele i przedmiot zabiegów oraz na stosowane środki, czyli formy i metody.

Ochronę przyrody należy rozumieć jako zespół idei, środków i działań zmierzających do zachowania, a w razie potrzeby także odtworzenia, obiektów przyrody w postaci pierwotnej lub możliwie mało zmienionej we wszystkich formach jej różnorodności, łącznie z warunkami i procesami decydującymi o ich trwałości. Można ją zatem traktować, jako zespół działań w interesie przyrody. Wynikające z niej korzyści mieszczą się przede wszystkim w sferze idei, tzn. poznania naukowego, edukacji, doznań estetycznych, inspiracji twórczej, zdrowia, poczucia egzystencji z przyrodą itp. Metody ochrony przyrody obejmują: prezerwację, konserwację, profilaktykę, restytucję i reintrodukcję. Określa się je mianem metod konserwatorskich, stosuje się zaś w celu utrzymania zagrożonych populacji roślin i zwierząt, biocenoz, ekosystemów i krajobrazów ${ }^{13}$.

Pojęcie ,ochrony środowiska” i nierozerwalnie z nim powiązane ,kształtowanie środowiska" odnosi się do zespołu idei, środków i działań, zmierzających do utrzymania go w stanie zapewniającym optymalne warunki bytowania człowieka oraz gwarantującym ciągłość najważniejszych procesów w biosferze jako podstawy produkcyjnej działalności człowieka. Z powyższego wynika, że „ochrona i kształtowanie środowiska” oznaczają poczynania zorientowane na zaspokojenie jego potrzeb. Konsekwencją realizacji tych celów są świadome, często daleko idące przekształcenia środowiska, połączone zwykle z odbudową (rekultywacją) komponentów wcześniej zniszczonych rabunkową gospodarką.

Oczywiste jest, że tak pojmowane pojęcie „ochrony i kształtowania środowiska” tylko w części może służyć utrzymaniu środowiska w stanie naturalnym i w maksymalnej różnorodności. Właśnie na tej płaszczyźnie zaznacza się związek między ideami ochrony przyrody a celami ochrony i kształtowania środowiska.

Świadomość ekologiczna jest to obszar świadomości społecznej odniesiony do środowiska przyrodniczego. W wymiarze jednostkowym kształtuje się ona jako rezultat procesu socjalizacji, w którym uczestniczy każdy z nas przez całe życie.

Składnikami świadomości ekologicznej są określone treści, nastawienia oraz emocje związane z przyrodniczym środowiskiem człowieka, powiązane i wzajemnie przenikające się z innymi formami świadomości społecznej. Za jej wyróżnik można przyjąć orientację, na preferowanie szacunku do przyrody oraz równowagę między nią a rozwojem ludzkości.

Wiedza ekologiczna to wiadomości i umiejętności dotyczące procesów zachodzących w ekosystemach, wiadomości o mechanizmach ekosystemów, jak też o zależnościach między różnymi formami działalności ludzkiej w środowisku przyrodniczym, a w szczególności o zanieczyszczeniach i zagrożeniach środowiska oraz sposobach profilaktyki.

Wyobraźnia ekologiczna to umiejętności przewidywania ekologicznych skutków działań ludzkich, zwłaszcza zdolność kompleksowego dostrzegania powiązań pomiędzy rozwojem cywilizacji i życiem ludzi a procesami zachodzącymi w środowisku przyrodniczym.

\footnotetext{
13 Ibidem, s. 13-14.
} 
Przejawia się ona przede wszystkim w trafności projektowania działań ekologicznie bezpiecznych ${ }^{14}$.

Głównym celem edukacji środowiskowej jest zmiana postaw społecznych wobec środowiska, w którym człowiek żyje, poprzez konstruowanie właściwych relacji: człowiek przyroda - środowisko oraz podnoszenie świadomości w tym zakresie ${ }^{15}$.

Poszczególne grupy społeczne i zawodowe, a także organizatorzy różnych szczebli zarządzania oraz decydenci, posiadają zróżnicowaną wiedzę i wyobraźnię ekologiczną. Pełniący te funkcje ludzie winni jednak mieć szczególną i niezbywalną cechę, a mianowicie uwrażliwienie na zachowanie równowagi między eksploatacją przyrody a jej ochroną, gdyż ich niewłaściwe działania mogą przynieść najwięcej szkód ekologicznych.

Rezultatem systematycznego kształtowania świadomości ekologicznej jest kultura jednostki, na którą składają się następujące elementy ${ }^{16}$ :

- wiedza na temat środowiska przyrodniczego;

- umiejętność widzenia specyfiki jak też złożoności zjawisk przyrodniczych oraz szukanie w nich współzależności i prawidłowości;

- gotowość do podejmowania działań wobec środowiska przyrodniczego;

- otwartość na wprowadzanie innowacji w kierunku bezpieczeństwa ekologicznego.

Znaczącą rolę w kształtowaniu tak szeroko rozumianej kultury ekologicznej odgrywa system ocen i wartości funkcjonujących w ramach aksjologiczno-normatywnej sfery świadomości ekologicznej. Powinien on dopełniać tradycyjny kanon społecznie aprobowanych wartości humanistycznych, akcentując w szczególny sposób autoteliczną wartość wszelkiego życia oraz podkreślając wagę środowiskowych komponentów decydujących o jego wartości.

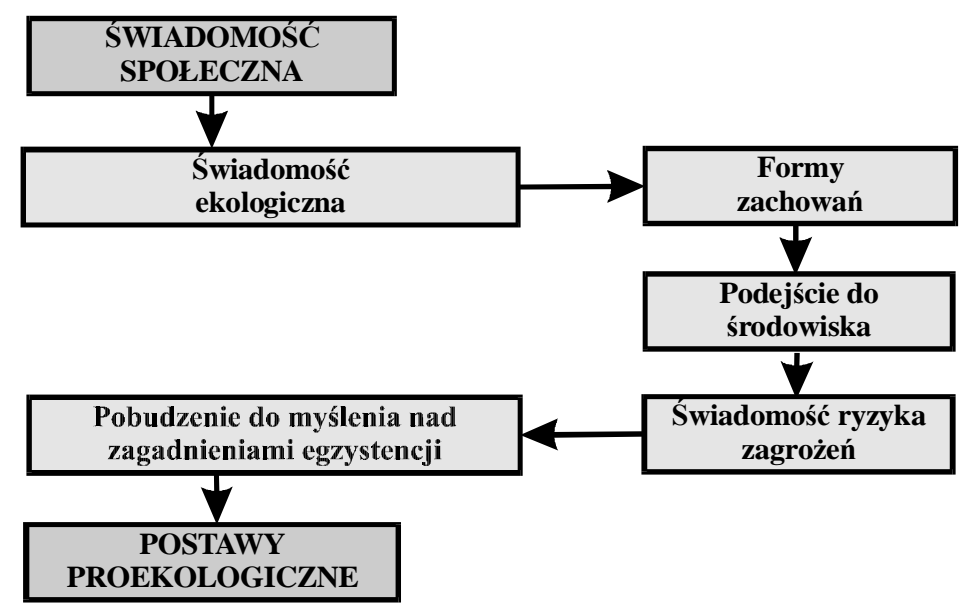

Rys. 1. Drogi kształtowania postaw proekologicznych

Źródło: S. Śladkowski, Edukacja ekologiczna...

${ }_{14}$ D. Cichy, H. Filipowicz, Edukacja ekologiczna wobec wspótczesności i wyzwań przyszłości, Warszawa 1993, s. 4.

15 S. Borsuk, Ekologia bez granic. Materiaty pokonferencyjne, Bydgoszcz 1994/95 s. 45.

${ }^{16}$ Porównaj: www.profesor.pl/publikacja,13611,Artykuly,Ksztaltowanie-swiadomosci. 

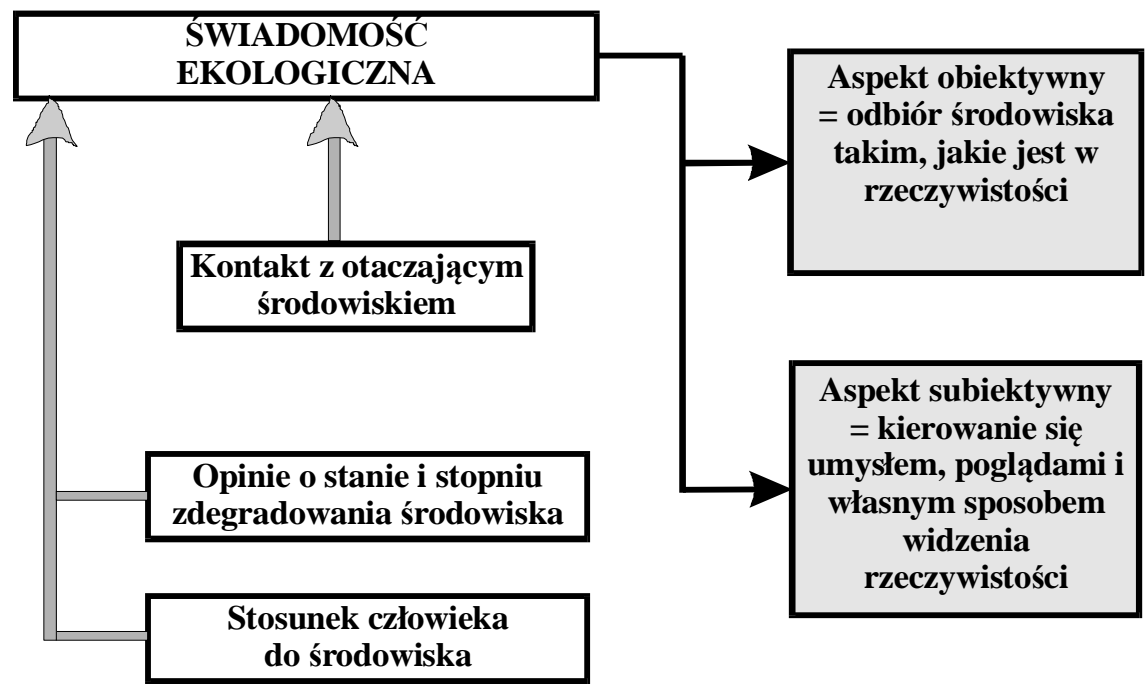

Rys. 2. Czynniki kształtujące świadomość ekologiczną

Źródło: S. Śladkowski, Edukacja ekologiczna...

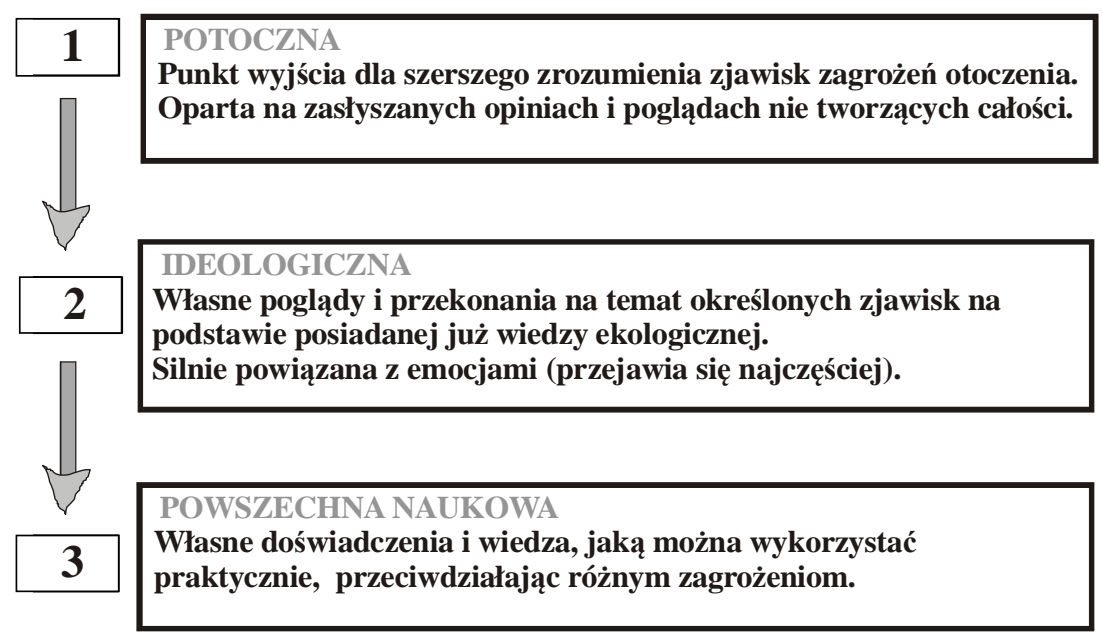

Rys. 3. Etapy kształtowania się świadomości ekologicznej w społeczeństwie

Źródło: S. Śladkowski, Edukacja ekologiczna...

$\mathrm{Z}$ tego punktu widzenia istotne jest wyodrębnienie wartości specyficznie ekologicznych, a więc wartości, które bezpośrednio wiążą się z ochroną środowiska człowieka oraz ochroną jego życia i zdrowia.

„Świadomość ekologiczna” postrzegana jest jako kategoria prawna, praktyczna i społeczna, wiodąca poprzez różne formy do kształtowania postaw proekologicznych. Jak każde zjawisko społeczne, jest rozpatrywana w aspekcie obiektywnym i subiektywnym. 
Z obiektywnego punktu widzenia dostrzegamy i odbieramy je takimi, jakimi są w rzeczywistości, natomiast subiektywizm pozwala spojrzeć na nie kierując się własnym umysłem, własnymi poglądami, własnym sposobem postrzegania otaczającej rzeczywistości. Z tego punktu widzenia można wyprowadzić wniosek: „świadomość ekologiczna” to społeczne zjawisko, ukazujące nasze poglądy i opinie o otaczającym świecie, kształtowane na drodze etapowego potocznego, ideologicznego i powszechnego pozyskiwania o nim wiedzy i pojmowane jako: ,poziom wiedzy społeczeństwa o stanie środowiska naturalnego, o zagrożeniach będących częścią każdej rozwijającej się cywilizacji, o zanieczyszczeniach oraz stopniu dewastacji i degradacji przyrody"17.

Można zatem stwierdzić, że świadomość ekologiczna ściśle zależy od wykształcenia i pozycji społeczno-zawodowej społeczeństwa. Rysunek 4 przedstawia etapy kształtowania się świadomości ekologicznej w skali czasu.

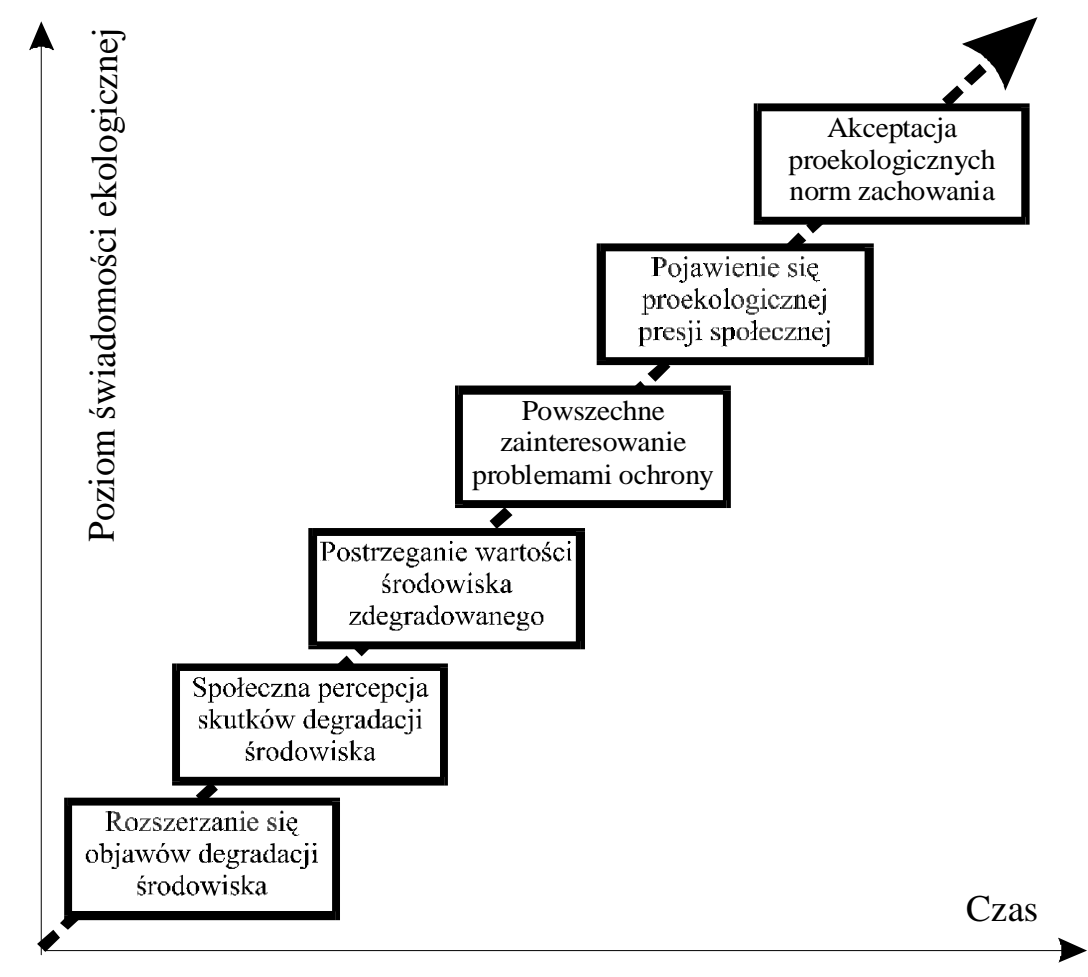

Rys. 4. Etapy kształtowania się świadomości ekologicznej w skali czasu

Źródło: S. Śladkowski, Edukacja ekologiczna...

Nie ulega wątpliwości, że środowisko przyrodnicze, jak wynika z analiz materiałów tematycznych, jest szeroko rozpowszechnioną w społeczeństwie polskim ,wartością uznawaną” i ,deklarowaną". Ów deklarowany, pozytywny stosunek do otoczenia nie znajduje

${ }_{17}$ S. Śladkowski, Edukacja ekologiczna. Wybrane problemy kształtowania postaw proekologicznych. Materiaty II Sympozjum Naukowego AMW, Gdynia 14 listopada 2002. 
jednak pokrycia w konkretnych wyborach wartości ekologicznych i zachowań świadczących o związkach z przyrodą. W sytuacji realnego wyboru, gdy trzeba czasem zrezygnować z dóbr cywilizacji w celu ochrony przyrody (czy jedynie kontaktu z nią), wartości ekologiczne przegrywają nawet na poziomie deklaracji słownych. Wyższą rangę uzyskują wtedy, gdy są pośrednio powiązane $\mathrm{z}$ warunkami bytu.

Rozdźwięk między zachowaniami głoszonymi w sferze ekologicznej a preferencjami dla użytkowych wartości ekologicznych jest wyrazem postawy społecznej związanej ze swoistym, nieodpowiedzialnym stosunkiem do otoczenia ${ }^{18}$.

Wyodrębnienie nowej płaszczyzny bezpieczeństwa państwa, jaką jest bezpieczeństwo ekologiczne ${ }^{19}$, definiowanej przez Śladkowskiego jako: , ,umowny system jednostek i instytucji wykonawczych połączonych jednolitym celem, zbiorami zadań itp., którego funkcjonowanie powinno przynieść pożądane efekty w przypadku różnorakich zagrożeń bez względu na to czy będą to zagrożenia pokoju czy okresu wojny". Tak zdefiniowane bezpieczeństwo ekologiczne staje się pojęciem złożonym i wieloznacznym i w zależności od autorytetów naukowych, może dotyczyć w skali mikro ekosystemu, jak i w skali makro terytorium państwa, kontynentu, oceanu wszechświatowego czy całego globu z przyległym kosmosem.

Ciszek pisze: „Nie zagłębiając się w szczegółowe definicje »bezpieczeństwo ekologiczne «można najogólniej wyjaśnić jako pożądany stan środowiska naturalnego, wolny od zagrożeń naruszających równowagę ekosystemów i biosfery. Tak pojmowane bezpieczeństwo ujmuje się w dwóch podstawowych płaszczyznach. W aspekcie negatywnym ogranicza się ono do eliminowania zagrożeń dla środowiska przyrodniczego. Natomiast w pozytywnym utożsamia się z szeregiem idei i koncepcji, które miałyby na celu przeciwdziałać powstaniu takich zagrożeń. W tym drugim ujęciu zamiast eliminacji zagrożeń postuluje się takie przeorientowanie dotychczasowych stosunków społeczno-gospodarczych, które nie prowadziłoby do powstania kryzysu ekologicznego" 20 .

Uważny czytelnik literatury przedmiotu zauważa, że chyba nieuprawnionym na obecnym etapie jest przypisywanie roli „pierwszych skrzypiec” bezpieczeństwu ekologicznemu i stosowanie go wymiennie z dziedzinami nauki takimi jak ekologia i ochrona środowiska.

\section{BUDOWA ZINTEGROWANYCH WSPÓLNOT EDUKACYJNYCH}

Nie trzeba nikogo przekonywać, że na poprawę naszego stosunku do zagadnień ochrony i kształtowania środowiska naturalnego człowieka ma wpływ globalna edukacja ekologiczna - prakseologia ${ }^{21}$.

Na poprzednich stronach przedstawiliśmy syntetycznie etiologię i anatomię realnych zagrożeń Planety Życia. W tej części rozważań pragniemy zająć się prakseologią poczynań poznawczych i praktycznych zmierzających do ich zmniejszania i zapobiegania we

\footnotetext{
${ }^{18}$ S. Śladkowski, Edukacja ekologiczna...

19 S. Śladkowski, Bezpieczeństwo ekologiczne Rzeczypospolitej Polskiej, Warszawa 2004, s. 10, http://www.rocznikbezpieczenstwa.dsw.edu.pl/fileadmin/user_upload/wydawnictwo/RBM/ RBM_artykuly/2013_10.pdf (dostęp: 11.10.2016 r.).

${ }^{20} \mathrm{http}: / /$ seib.uksw.edu.pl/sites/default/files/tom_10_1_2_mariusz_ciszek_bezpieczenstwo_ekologiczne_i_zrownowazony_rozw\%C3\%B3j_w_aspekcie_strategii_bezpieczenstwa_narodowego. pdf (dostęp: 11.10.2016 r.).

21 J. Borgosz, Globalna edukacja ekologiczna - prakseologia, „Wojsko i Wychowanie” 1992/12.
} 
wszystkich dziedzinach życia jednostkowego, grupowego, narodowego i międzynarodowego.

Na temat tak rozumianej prakseologii ekologicznej toczyły się i trwają ostre kontrowersje i dyskusje, z których wyłaniają się różne koncepcje. Wśród nich najważniejsze są przynajmniej cztery.

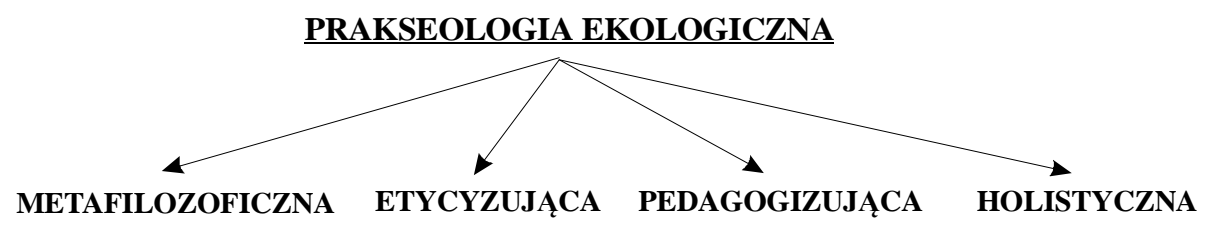

Metafilozoficzna - opowiada się za tworzeniem nowej metafizyki (filozofii) przyrody, wznoszącej się ponad dotychczasowe jej kierunki oraz ujmującej świat natury przede wszystkim z perspektywy życia i jego racjonalnej prolongaty.

Etycyzujaca - postuluje tworzenie nowego, nieistniejącego dotąd działu etyki globalnej - etyki ekologicznej i internalizowanie jej zasad w świadomość ludzką na wszystkich szczeblach kształcenia i wychowania.

Pedagogizująca - optująca za maksymalnym przepajaniem treściami ekologicznymi wszystkich programów i przedmiotów nauczania, pod kątem harmonijnego współżycia człowieka z przyrodą.

Holistyczna (całościowa) lub w innej terminologii: strukturalistyczna preferuje strukturalną przebudowę całego świata i stawianie sobie za cel stworzenie ,nowego ładu międzynarodowego" jako głównego warunku ratowania zagrożonej Planety Ziemi ${ }^{22}$.

Najbardziej nam bliska jest koncepcja pedagogizująca, dlatego pozwolimy sobie ją wyróżnić i przedstawić jej założenia. Koncepcja pedagogizująca, zgodnie ze swą nazwą, optuje za tworzeniem szeroko rozumianej pedagogiki ekologicznej, obejmującej swym zakresem teorię nauczania i wychowania proekologicznego, proprzyrodniczego. Ale podobnie, jak w procesie formowania się każdej nowej dyscypliny, tak i w tym istnieją różne podejścia zarówno do sposobu jej rozumienia, jak i uprawiania, (stosowania). Chodzi przede wszystkim o to, czy ma ona być autonomicznym działem myślenia i praktyki pedagogicznej, czy integralną częścią pedagogiki ogólnej i społecznej, czy też wreszcie interdyscyplinarnym, przenikającym wszystkie nauki przyrodnicze, techniczne i społeczne myśleniem, składającym się równocześnie z warstwy teoretycznej i aksjologicznej, opisowej i normatywnej, kształceniowej i wychowawczej.

Spośród trzech wymienionych możliwości za najbardziej racjonalną uważa się tę trzecią, tj. propozycję pedagogiki jako interdyscyplinarnego myślenia proekologicznego, adresowanego przede wszystkim do młodzieży szkół technicznych wszelkich typów. Składają się na to przynajmniej cztery powody:

Po pierwsze - wyalienowany świat bytów techniki okazał się i nadal stanowi główne zagrożenie żywotności bioróżnorodności przyrody.

Po wtóre - kształceniu techników wszelkiego rodzaju nie towarzyszy, jak dotąd, żadna edukacja proekologiczna. O ile pewne elementy tej ostatniej przejawiają się w przygotowa-

22 Ibidem, s. 39. 
niu przyrodników i humanistów, o tyle w kształtowanym wizerunku pracowników technicznych nie ma ich w ogóle. Tymczasem to od nich w głównym stopniu zależeć będzie nie tylko „uczłowieczone” oblicze techniki, szerzej - technologii, lecz także jej proekologiczny, proprzyrodniczy charakter.

Pozostaje aktualne, więc pytanie czy nadal będzie to technologia „,brudna”, destrukcyjna, czy technologia „czysta”, wkomponowana w otoczenie przyrodnicze.

Po trzecie - podmioty przyrodnicze w szkołach są mocno zdezintegrowane, wąsko wyspecjalizowane, dające uczniom wycinkową wiedzę o poszczególnych fragmentach, czy wręcz skrawkach przyrody. W wyniku tego są oni pozbawieni całościowego jej obrazu, zawłaszcza ekosystemowego. Poszukuje się zatem przedmiotu, który by ten zdezintegrowany obraz świata przyrodniczego integrował. Jedni uważają, że taką dyscypliną mogłaby być pedagogika ekologiczna właśnie, inni, że ekologia lub ,przyroda” po prostu, wreszcie jeszcze inni, że biologia jako nauka o życiu.

Po czwarte - we wszystkich przedmiotach traktujących o przyrodzie, jej bioróżnorodności dominuje pozytywizm i strukturalizm dydaktyczny. Polega on na przedkładaniu opisu rejestracji i struktury nad ukazywaniem miejsca, roli i znaczenia poszczególnych bytów, jestestw i zjawisk przyrody dla zachowania równowagi ekosystemu oraz prolongaty zdrowej biosfery, a także nad propagowaniem jakościowo nowej kultury ekologicznej w życiu każdego człowieka ${ }^{23}$.

\section{BADANIA WŁASNE}

Autorzy ustalając temat badań, rozumianych zarówno jako obiekt i przedmiot pracy chcieli zorientować się w tym co jest znane, a co jeszcze nie (nie określając poziomu i skali znania, i nieznania), czyli na zdobyciu wiedzy na temat badania.

Autorzy zastanawiają się stawiając pytanie: Czy uprawnione staje się ewolucyjne „przejście” pojęć typowych i przypisywanych ekologii do bezpieczeństwa ekologicznego? - Jakie jest rozumienie wymienionych pojęć?

Wszystkie wyrazy, ze względu na ich cechy gramatyczne i znaczeniowe można pogrupować na części mowy i części zdania.

Słowo ekologia w częściach mowy jest rzeczownikiem, natomiast w zdaniu jest podmiotem. Bezpieczeństwo ekologiczne składa się z dwu wyrazów i odpowiednio pełnią one funkcję bezpieczeństwo jest rzeczownikiem, a ekologiczne przymiotnikiem. Przymiotnik określa rzeczownik i w tym wypadku podlega stopniowaniu opisowemu (I ekologiczny, II bardziej ekologiczny, III najbardziej ekologiczny). Odpowiednio w zdaniu są podmiotem i przydawką.

Bogactwo języka polskiego, jak wykazała wcale niepogłębiona analiza nie upoważnia uważnego uczestnika zajmującego się zagadnieniami ekologii i bezpieczeństwa ekologicznego do stosowania pojęć zamiennie. Ekologia jest nauką i w każdym zdaniu będzie pełniła rolę podmiotu. Bezpieczeństwo ekologiczne jest neologizmem frazeologicznym typu bezpieczeństwo podatkowe.

Z całą pewnością można stwierdzić, że populacja ludzka będzie je rozumiała różnie. Część tej różnorodności chcemy zaprezentować. Podstawowym celem przeprowadzonych badań było poznanie rozróżniania słów - ekologia i bezpieczeństwo ekologiczne.

23 Ibidem, s. 42. 
Słowa te nie były definiowane przez autorów ankiety. Zadaniem ankietowanych było odpowiedzenie na pytania. Pytania zostały tak skonstruowane, że odwoływały się do konkretnej wiedzy, jak również „,czucia” zagadnienia w odbiorze osobistym i społecznym. Badania przeprowadzono wśród kobiet i mężczyzn na przełomie marca i kwietnia 2015 roku. Do badań wytypowano 60 osób po 30 z każdej płci. Grupa badanych była z góry określona i dotyczyła trzech roczników urodzenia: 1956, 1957, 1958. W czasie wypełniania ankiety ankietowani mieli odpowiednio po 59, 58, 57 lat. Tak celowo dobrana próba w końcówce lat 80. ubiegłego wieku była już absolwentami uczelni wyższych, w wieku nieprzekraczającym 30 lat i uczestniczyła w procesie przemian ustrojowych w Polsce gdzie budziła się świadomość ekologiczna rodaków (patrz wstęp).

Na wykresie 1 przedstawiono typ ukończenia uczelni przez respondentów.

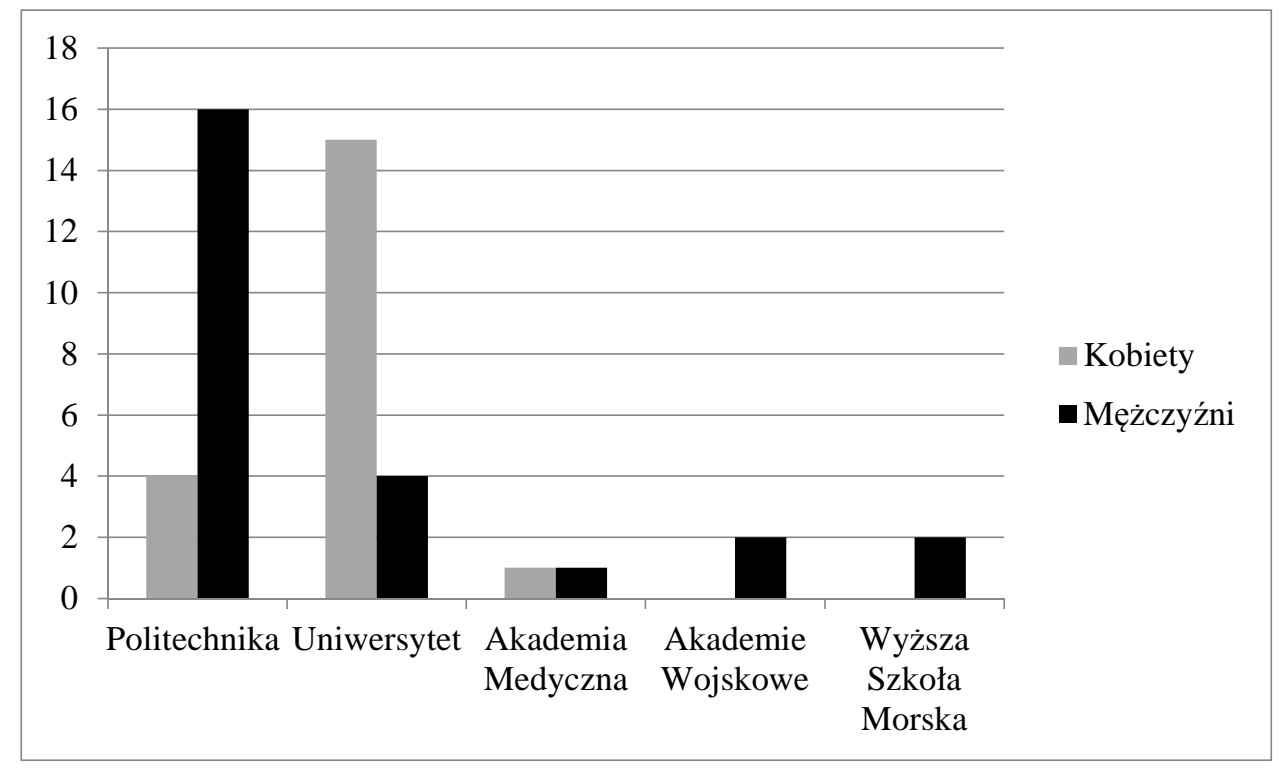

Wykres 1. Typ ukończenia uczelni przez respondentów.

Źródło: badania własne.

Autorzy operują dawnym nazewnictwem uczelni obowiązującym w okresie otrzymania dyplomu przez badanych. Kobiety zdominowały wykształcenie uniwersyteckie. Równowagę wykształconych osiągnięto na Akademii Medycznej. Politechniczne wykształcenie zdominowali mężczyźni kończąc odpowiednio politechnikę, akademie wojskowe i Wyższą Szkołę Morską.

Na wykresach 2 i 3 przedstawiono odpowiedzi ankietowanych kobiet i mężczyzn, którym zadano pytanie: Jakie określenia stosują do opisu poszczególnych zagadnień? 

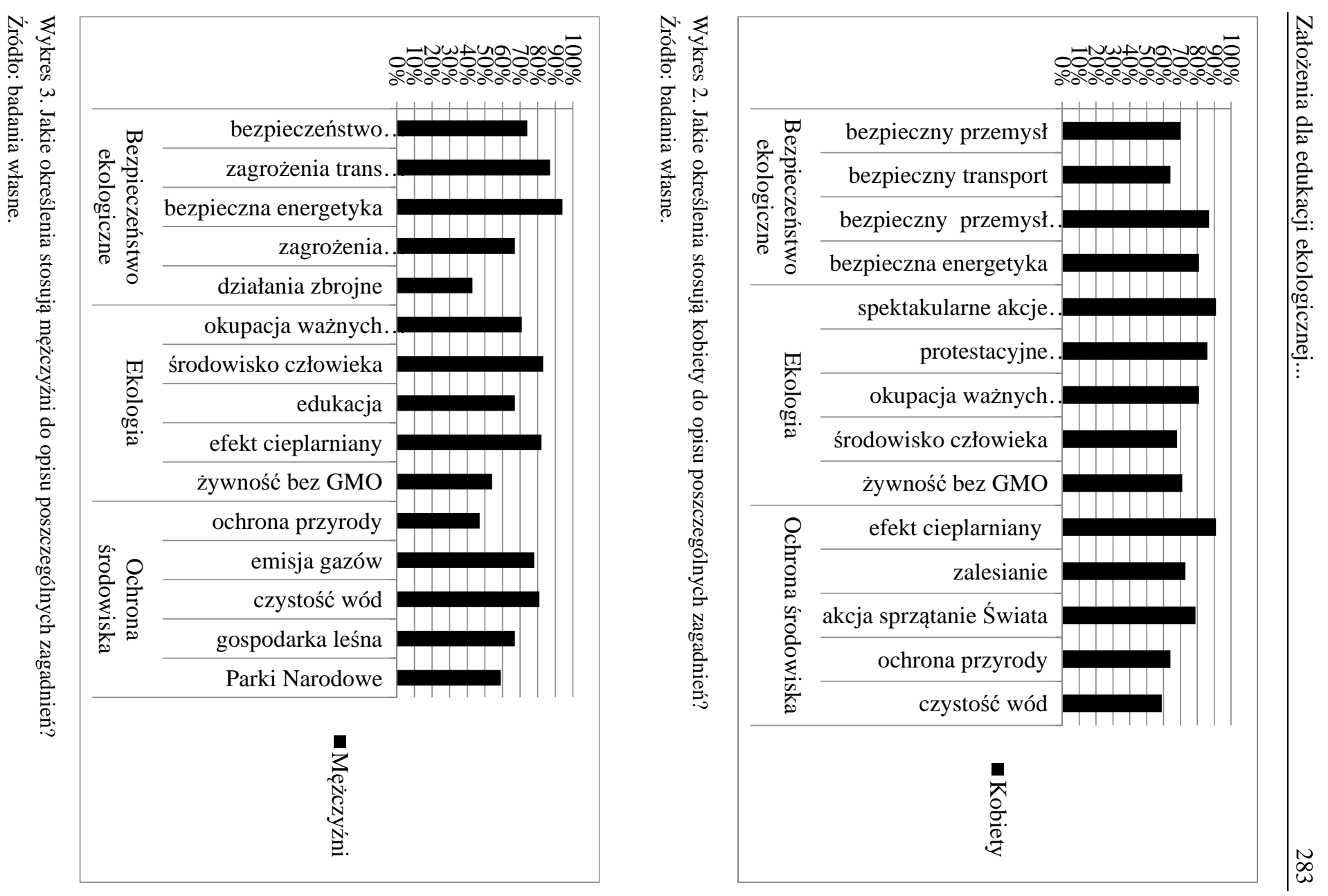
Określenia, które wybrały kobiety dla poszczególnych zagadnień przedstawia wykres 2. Dla bezpieczeństwa ekologicznego ankietowane wybrały następujące określenia: bezpieczny przemysł kopalin energetycznych (87\%), bezpieczna energetyka (81\%), bezpieczny przemysł (70), bezpieczny transport (64\%). Dla określenia ekologii użyły takich pojęć jak: spektakularne akcje protestacyjne Grenpeace (91\%), protestacyjne blokowanie dróg (86\%), okupacja ważnych budynków (81\%), żywność bez GMO (71\%), środowisko człowieka (68\%). Natomiast ochronę środowiska opisują jako: efekt cieplarniany (91\%), akcja „Sprzątanie Świata” (79\%), zalesianie (73\%), ochrona przyrody (64\%), czystość wód $(59 \%)$.

Na wykresie 3 znajdują się określenia, które wybrane zostały przez mężczyzn dla poszczególnych zagadnień. Dla bezpieczeństwa ekologicznego respondenci wybrali następujące określenia: bezpieczna energetyka (94\%), zagrożenia trans graniczne (87\%), bezpieczeństwo państwa (74\%), zagrożenia przemysłowe (67\%), działania zbrojne (43\%). Przy określeniu ekologii pojawiły się pojęcia: środowisko człowieka (83\%), efekt cieplarniany (82\%), okupacja ważnych budynków (71\%), edukacja (67\%), żywność bez GMO (54\%). Natomiast określając ochronę środowiska ankietowali użyli zwrotów: czystość wód (81\%), emisja gazów (78\%), gospodarka leśna (67\%), Parki Narodowe (59\%), ochrona przyrody $(47 \%)$.

Oceniając znajomość zagadnień ochrony środowiska, ekologii i bezpieczeństwa ekologicznego (wykres 4) przez kobiety i mężczyzn można zauważyć, że płeć nie odgrywa w tej kwestii znaczącej roli. Na podobnym poziomie plasuje się znajomość ekologii (kobiety 89\%, mężczyźni 77\%) jak i ochrony środowiska (kobiety 84\%, mężczyźni 86\%). Zdecydowanie gorzej wypada znajomość pojęcia bezpieczeństwa ekologicznego i to zarówno wśród kobiet (17\%) jak i mężczyzn (28).

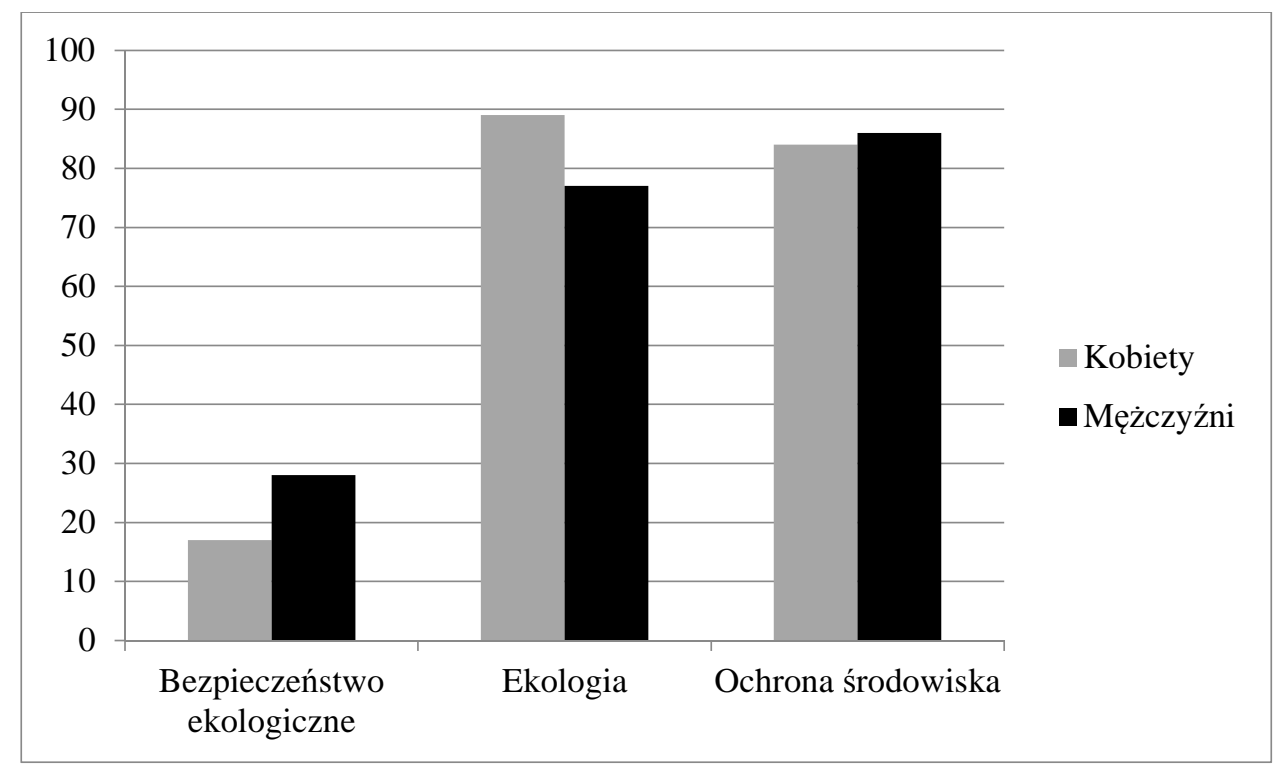

Wykres 4. Porównanie procentowej znajomości poszczególnych zagadnień kobiet i mężczyzn.

Źródło: badania własne. 
Wyniki te mogą świadczyć o tym, że znajomość zagadnień bezpieczeństwa ekologicznego jest na tak niskim poziomie, ponieważ jest to pojęcie stosunkowo nowe oraz złożone i wieloznaczne. Nie bez znaczenia jest fakt, że w środkach masowego przekazu (telewizja, radio) jak i prasie codziennej (niespecjalistycznej) badane pojęcia często stosowane są zamiennie. Ta zamienność wymaga dalszych badań, które podjęli autorzy a ich wyniki przedstawią w kolejnym artykule. Badaniom zostanie poddane rozumienie pojęć i słownictwa stosowanego w: Strategii Bezpieczeństwa Narodowego Rzeczypospolitej Polskiej z: 2003, 2007 i 2014 roku.

\section{ZAKOŃCZENIE}

Zdajemy sobie w pełni sprawę, że podane $\mathrm{ABC}$ ekologii nie w pełni zaspokoiło ciekawość odbiorcy, ale jednocześnie jesteśmy przekonani, że ta encyklopedyczna wiedza pozwoli mu przyjrzeć się realizowanej edukacji ekologicznej. Termin „ekologia” wszedł do słownika potocznego i zyskał w nim pewne nowe aspekty oraz znaczenia, które odbiegają od przedmiotu ekologii jako nauki. Mówimy np., że coś jest „ekologiczne” i myślimy wtedy: naturalne, oszczędne, w zgodzie ze środowiskiem, nieszkodliwe, nietoksyczne, bezpieczne, wielokrotnego użytku itd. Mianem ,ekologiczne” określamy poszczególne działania (korzystanie z komunikacji miejskiej, segregacja odpadów na poziomie gospodarstwa domowego, zadrzewianie nieużytków, nieużywanie jednorazowych opakowań typu PET), inicjatywy społeczne: dzień Ziemi, sprzątanie świata czy nawet kierunki myślenia, nawiązując tym samym do filozofii ekologicznej, nie zaś ekologii, jako nauki przyrodniczej.

Przedmiotem naszych rozważań były wybrane zagadnienia globalnej edukacji ekologicznej - prakseologii, w których pozwoliliśmy sobie przedstawić własny punkt widzenia. Jest rzeczą oczywistą, że jest on jednocześnie na tyle ogólny i na tyle szczegółowy na ile pozwoliły na to z zamysłem przyjęte ograniczenia. Przekonani jesteśmy o tym, że zagadnienia przedstawione $\mathrm{w}$ tym artykule zwrócą uwagę ludzi odpowiedzialnych za szeroko rozumianą globalną edukację ekologiczną.

\section{LITERATURA}

[1] Bieszczad St., Sobota J. (red.), Zagrożenie, ochrona i kształtowanie środowiska przyrodniczo-rolniczego, Wrocław 1993.

[2] Borgosz J., Globalna edukacja ekologiczna-prakseologia, ,Wojsko i wychowanie” 1992/12.

[3] Borsuk S., red., Ochrona i ksztaltowanie środowiska, Toruń-Bydgoszcz 1994.

[4] Borsuk S., Ekologia bez granic. Materiaty pokonferencyjne, Bydgoszcz 1994/95.

[5] cejsh.icm.edu.pl/cejsh/element/...PRM_2011-1-2_04_Kozlowski.pdf.

[6] Cichy D., Filipowicz H., Edukacja ekologiczna wobec wspótczesności i wyzwań przyszłości, Instytut Badań Edukacyjnych, Warszawa 1993.

[7] http://seib.uksw.edu.pl/sites/default/files/tom_10_1_2_mariusz_ciszek_bezpieczenstwo_ ekologiczne_i_zrownowazony_rozw\% $\%$ \% B3j_w_aspekcie_strategii_bezpieczenstwa_ narodowego.pdf.

[8] https://repozytorium.umk.pl/bitstream/handle/item/1215/DOMERACKI\%20Piotr,\%20TYBURSKI $\% 20 \mathrm{~W} \%$ C5\%82odzimierz\%20-\%20Edukacja \%20do\%20ZR.pdf?sequence $=1$

[9] Śladkowski S., Edukacja ekologiczna. Wybrane problemy ksztattowania postaw proekologicznych. Materiaty II Sympozjum Naukowego AMW, Gdynia 14 listopada 2002. 
[10] Śladkowski S., Bezpieczeństwo ekologiczne Rzeczypospolitej Polskiej, AON, Warszawa 2004, http://www.rocznikbezpieczenstwa.dsw.edu.pl/fileadmin/user_upload/wydawnictwo/RBM/RBM_artykuly/2013_10.pdf

[11] Zakrzewski G., Koncepcja edukacji środowiskowej w MW RP, „Przegląd Morski” 1995/3.

[12] Żmudziński L. (red.), Morskie Obszary Chronione w polskiej strefie brzegowej-zakres, forma i sposoby ochrony, Materiały z sympozjum Centrum Biologii Morza PAN, Gdynia, 26 lutego 1998.

\section{ASSUMPTIONS FOR ENVIRONMENTAL EDUCATION OR ENVIRONMENTAL SAFETY}

This article contains a short history of science called ecology and presents its basic definitions and scientists who have introduced a new terminology to the ecology dictionary.

In further parts the authors indicate the relationship between environmental awareness and environmental education. The authors quoted the information that shows the status of environmental education for modern society.

Environmental education plays an important role in the modern world that affects our environment very fast. It is the process of psycho - pedagogy, which has an impact on environmental awareness. It is an important part of our adaptation to the environment where we operate. Its main task is to indicate threats of the natural environment and to transfer the theoretical knowledge, which should be embodied in practical action.

The aim of environmental education should be shaping the realm of emotion, which will increase the efficiency of perception, thinking and acting. To fulfill its tasks, it should cover all levels of education, both formal and informal. First of all, we need to educate young generations and thus shape the mentality of society.

The concern about the place where we live, work and rest should lead to increased efforts to promote environmental education in both ways theoretical and practical. This concern should result from the existing ecological and environmental hazards that are dangerous to health and life of modern man. The authors wonder whether the evolutional "transfer" of terms linked with and typical for ecology to ecological security is legitimate.

Keywords: ecology, environmental, consciousness, education, imagination, ecological safety.

DOI: $10.7862 /$ rz.2017.hss.58

Przestano do redakcji: listopad 2017 r.

Przyjęto do druku: wrzesień 2017 r. 